\title{
Relationship between groundwater chemistry and the Precambrian basement rocks on eastern Bornholm, Denmark
}

\author{
Peter Gravesen, Rasmus Jakobsen and Bertel Nilsson
}

Bornholm is situated south of Sweden, in the SorgenfreiTornquist Zone (Fig. 1). The Precambrian basement on northern and eastern Bornholm consists of different types of granitic and gneissic rocks with pegmatites, aplites and dolerite dykes (Callisen 1934). The age of the granite and gneiss is c. $1455 \mathrm{Ma}$ (Waight et al. 2012).

This study deals with the Østerlars-Svaneke area north of Paradisbakkerne and focuses on the geology and groundwater chemistry of the groundwater aquifers in the Bornholm gneiss, Paradisbakke migmatite and Svaneke granite (Fig. 2). The geology and groundwater conditions in part of the study area were described by Gravesen et al. (2011, 2013, 2014). Miljøcenter Roskilde (2009) described the groundwater conditions at the Østerlars and Østermarie waterworks. The aim of this paper is to show the relations between rock composition, mineral alteration and groundwater chemistry in the low-permeability rocks using existing data from outcrops and boreholes.

\section{Methods}

Data on geology and groundwater chemistry were obtained from the Jupiter database at the Geological Survey of Denmark and Greenland. Information from more than 200 boreholes reaching basement rocks is included; in addition some data on the Quaternary sediments were available. Of the 200 boreholes, data on groundwater chemistry from 29 boreholes were available, in some boreholes as a series of analyses. Data on fractures were collected from outcrops in the area during field work in 2011.

\section{Precambrian rock distribution and petrography}

Three main rock types are found in the area. The westernmost type is the medium-grained, foliated Bornholm biotite gneiss which is usually dark grey, light grey or red grey; small areas with red grey granite or other colours also occur (Callisen 1934; Platou 1970). The dark grey type consists of Kfeldspar (35\%), quartz (25\%), plagioclase (25\%), biotite (7\%), hornblende (5\%) and magnetite (3\%) and minor amounts of apatite and traces of zircon, allanite, epidote and calcite (Micheelsen 1961). Light grey quartz gneiss and quartzitic types have a larger content of quartz and are often banded. Large crystals of apatite and plagioclase occur. The gneiss also contains skarn bodies with garnet and epidote or lenses with wollastonite, epidote and garnet.

Fine- to medium-grained Paradisbakke migmatite occurs in a restricted area between the Bornholm gneiss and the Svaneke granite (Fig. 1) and consists of almost parallel, light grey granitic quartz-feldspar veins in a darker matrix. The migmatite consists of K-feldspar (35\%), quartz (23\%), plagioclase (25\%), hornblende (8\%), biotite (7\%), magnetite (1\%) and titanite (1\%), zircon and traces of allanite; calcite and epidote occur in the darker part but are rare in the lighter part (Micheelsen 1961).

The Svaneke granite consists of K-feldspar (36\%), plagioclase $(26 \%)$ and quartz (25\%) with biotite (7\%), hornblende (2\%) and contains minor amounts of magnetite and titanite,

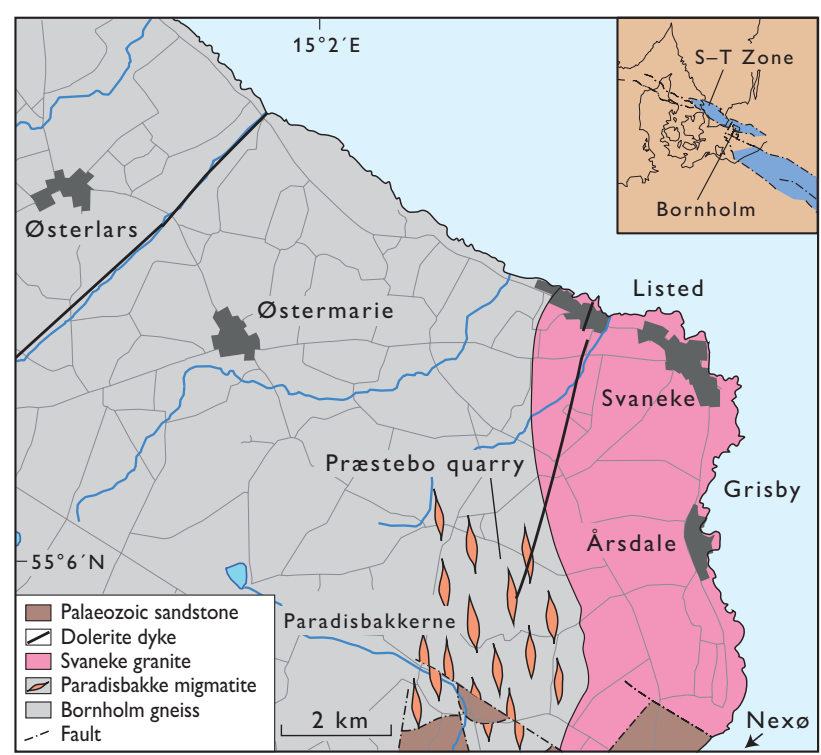

Fig. 1. Geological map of part of eastern Bornholm, modified from Varv (1977). Inset: Bornholm's location in the Sorgenfri-Tornquist Zone (S-T Zone). 
as well as traces of apatite, zircon, epidote, allanite, calcite and flourite (Micheelsen 1961). Many small inclusions rich in mafic minerals also occur and locally the content of apatite and flourite in the rock appears to be higher. The granite is usually coarse-grained and greyish red but occasionally medium to coarse grained and yellow, yellow red or dark grey.

The Svaneke granite can be divided into four types and a border facies bordering the gneiss and migmatite (Platou 1968, 1970). The border facies is commonly strongly lineated but also has non-lineated parts and a varying content of dark minerals. Svaneke granite type I is light yellow and varies in grain size, and biotite is weakly altered to chlorite; this type occurs around Svaneke and Listed. Svaneke granite type II covers an area from the north coast and inland between the border facies and type I and types III and IV. The rock is medium to coarse grained and among the dark minerals hornblende, biotite and sphene are dominant. The plagioclase and the dark minerals are weakly altered to unaltered. Svaneke granite type III covers a large area along the east coast from Grisby to the Palaeozoic sandstone north of Nexø and is exposed at several places. The rock is light yellow to light yellow red. The Svaneke granite type IV occurs as lenses in type III; seen for example at Årsdale. It is a dark red, coarse-grained rock and both the plagioclase and the dark minerals are strongly altered.

In types III and IV the hornblende, pyroxene and biotite may be altered to green chlorite, and magnetite is altered to hematite. Especially in the coastal area around Årsdale and southwards towards Nexø the granite is strongly weathered and altered and contains 3-7\% chlorite. The rock readily disintegrates to form coarse gravel (Årsdale gravel) and the fracture surfaces of the granite are covered by clayey material of green chlorite and yellow-brown limonite.

\section{Fracture systems}

Four fracture systems have been identified in the area. The fracture systems are seen in quarries in the Paradisbakke migmatite along the northern rim of Paradisbakkerne, in coastal exposures of the Bornholm gneiss towards the north and in exposures of the Svaneke granite towards the east and the north (von Bubnoff 1942). Two vertical fracture sets with orientations NNE-SSW and ESE-WNW and two horizontal fracture sets are found. The 3D fracture network of crossing vertical, subvertical, horizontal and subhorizontal fractures forms the groundwater aquifers in the rocks. The vertical fractures are mainly transport paths for infiltrating water to the groundwater table, whereas the horizontal fractures form conduits for groundwater over long horizontal distances. Horizontal fractures are present at least up to $90 \mathrm{~m}$ depth below the ground surface; two other shallower sets of horizontal fractures are also found (Gravesen $e t$ al. 2014). Information from boreholes shows that groundwa-
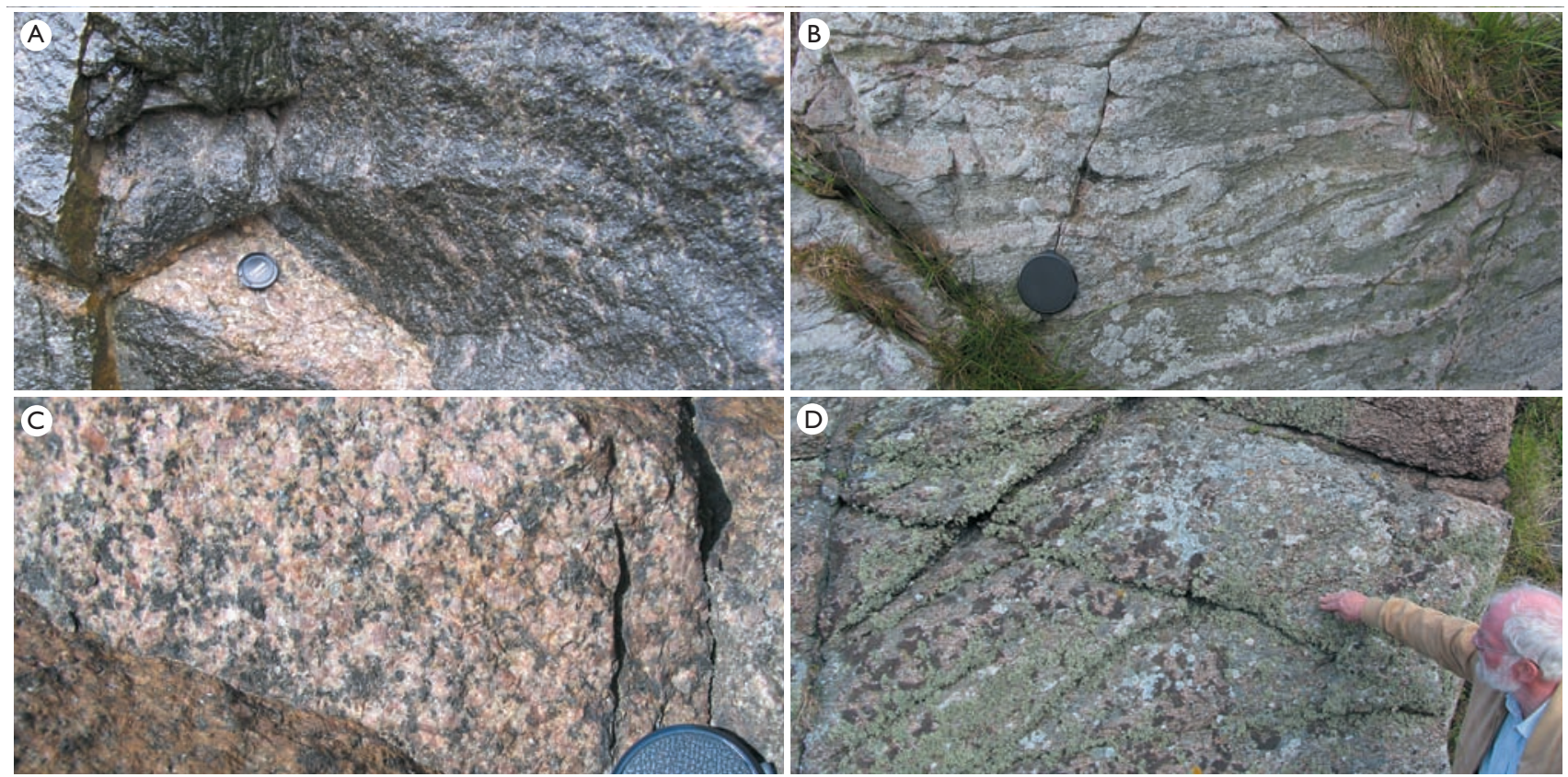

Fig. 2. The different basement rock types. A: Paradisbakke migmatite with pegmatite body, Præstebo quarry. B: Banded and folded Bornholm gneiss, west of Listed, C: Svaneke granite, east coast of Bornholm, D: Weathered and fractured Svaneke granite, east of Listed. Photographs: Merete Binderup. 


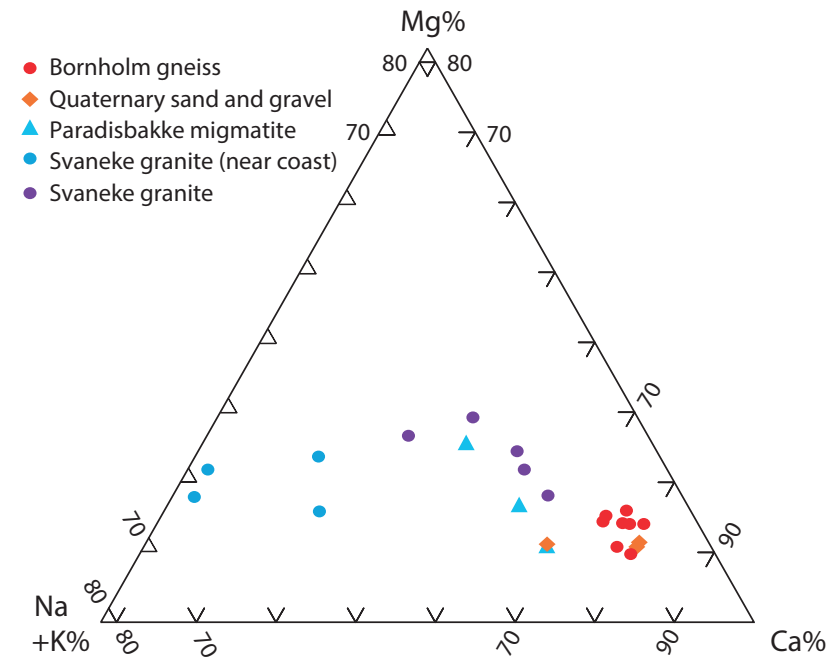

Fig. 3. Ternary plot showing the relative distribution (on equivalent basis) of major cations ( $\mathrm{Mg}, \mathrm{Ca}$ and $\mathrm{Na}+\mathrm{K})$ in water samples from wells in different granite types. Part of the triangle was removed for clarity.

ter is pumped up from both shallow and deep fractures, the deepest ones $144 \mathrm{~m}$ below ground surface.

In the weathered rocks iron-bearing minerals are oxidised to yellow-brown clayey iron compounds and the dark minerals are altered to clayey green chlorite that is found on the fracture surfaces. Clayey material found on fracture surfaces at depths up to $70 \mathrm{~m}$ probably have an impact on the chemistry of the groundwater.

\section{Groundwater chemistry}

The number of chemical analyses of groundwater from wells in the study area is unfortunately rather small and some parameters, especially from the Svaneke granite, appear imprecise, e.g. $\mathrm{pH}$ values with only one digit. Measurements of $\mathrm{Al}$ concentrations are usually missing, which makes it impossible to assess the saturation state of Al-silicates. However, measured concentrations of major cations and measured alkalinity (except for one outlier) appear reliable. Speciation and calculations of mineral saturations using the software PHREEQC (Parkhurst \& Appelo 2012) based on the parameters available, with reservations for the approximate $\mathrm{pH}$ values indicates that groundwater in all samples is slightly supersaturated with respect to calcite. A few analyses included measurements of sulphide and trace metal concentrations and the PHREEQC calculations indicate that concentrations of trace metals such as $\mathrm{Pb}$ and $\mathrm{Zn}$ are likely controlled by sulphide phases.

Based on the major cations dissolved in the groundwater, it appears that weathering of the different granite types leads to different water chemistry. In a ternary plot (Fig. 3)

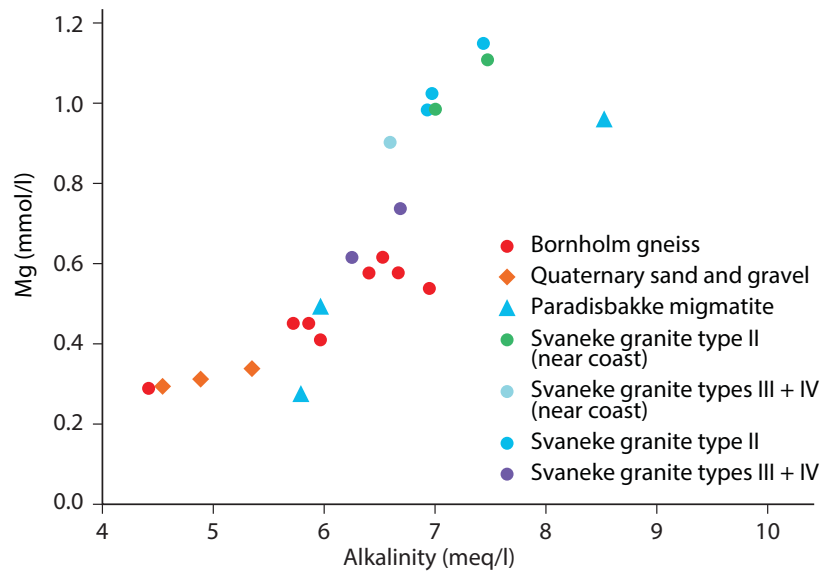

Fig. 4. Plot of Mg concentration versus alkalinity, which is considered an indicator for the degree of weathering.

showing the relation between (charge equivalents) of $\mathrm{Ca}$, $\mathrm{Mg}$ and $\mathrm{Na}+\mathrm{K}$ in the water, the Bornholm gneiss is barely distinguishable from samples that come from aquifers in Quaternary sand and gravel, whereas water samples from the Paradisbakke migmatite and Svaneke granite are enriched in $\mathrm{Mg}$ and to some extent in $\mathrm{Na}$. $\mathrm{Na}$ enrichment is most pronounced in samples collected close to the coast. High $\mathrm{Na}$ concentrations are correlated with high $\mathrm{Cl}$ concentrations, which indicates deposition of sea salts by dry and wet deposition. Although also present in seawater, high $\mathrm{Mg}$ concentrations do not show any correlation with $\mathrm{Cl}$ concentrations, which indicates that $\mathrm{Mg}$ comes from weathering reactions. This is examined in more detail in Fig. 4, where Mg concentration versus alkalinity is plotted, which is a general indicator for the degree of weathering. As infiltrating water rich in carbonic acid from the soil zone reacts with the rock, the carbonic acid is used and the alkalinity in the water increases. A sample from the Svaneke granite with an unusually low alkalinity of $1.6 \mathrm{meq} / \mathrm{l}$ is considered an outlier and was removed from the dataset in Fig. 4.

It should be noted that the groundwater may have passed through several rock types before reaching the borehole where it was sampled, and there are no reliable groundwater ages so the relative weathering rates based on the water chemistry of the different rocks implies that the bulk water samples from the boreholes represent comparable residence times of the water. There are only three Paradisbakke migmatite samples; they indicate both low and high rates of weathering. Two ${ }^{14} \mathrm{C}$ datings have been made on water from the Paradisbakke migmatite, the ages are rather uncertain, but the oldest of these dates is from the borehole with the highest $\mathrm{Mg}$ concentration and alkalinity. Based on the low alkalinity of the water, samples from the Quaternary aquifers indicate the lowest rate of weathering, which could be expected. Of 
the crystalline rocks, the Bornholm gneiss appears to have the lowest weathering rate. Two boreholes in the Bornholm gneiss have been sampled using two pumps, giving water from different depths (Rasmussen et al. 2007). These samples show that the lowermost samples have much higher concentrations of fluoride (1.1 and $1.9 \mathrm{mg} / \mathrm{l}$ compared to c. 0.6 and $0.4 \mathrm{mg} / \mathrm{l}$ for the mixed samples) and boron ( 34 and $47 \mu \mathrm{g} / \mathrm{l}$ compared to $c .20 \mu \mathrm{g} / \mathrm{l}$ for the mixed samples), presumably released from either amphiboles or biotite, perhaps apatite in the case of fluoride. The higher concentrations at depth indicate a longer residence time, but the PHREEQC calculations indicate that the water is close to saturation for apatite so using fluoride concentrations to quantify residence time could be difficult.

There is no obvious relation between the different types of Svaneke granite and the apparent weathering rates based on $\mathrm{Mg}$ and alkalinity concentrations in the groundwater. Still, weathering rates appear to increase from the inland Svaneke granite types III andIV over the near coastal Svaneke granite types III and IV to the Svaneke granite types I and II that show the highest $\mathrm{Mg}$ concentration and alkalinity, though types I and II visually appear to be the least weathered. Still the water chemistry indicates that the Svaneke granites weather faster than the other granite type, this could be related to the many small, mafic, mineral-rich inclusions found in the Svaneke granite or could reflect a general, primary, textural difference that leads to increased weathering rates.

\section{Conclusions}

In spite of the small differences seen in terms of bulk mineralogy of the granitic and gnessic rocks and the subtypes there is a distinct difference in the observed groundwater chemistry. Based on the major cations, especially $\mathrm{Mg}$, it appears that weathering of the different basement rock types leads to different water chemistry.

\section{References}

Callisen, K. 1934: Das Grundgebirge von Bornholm. Danmarks Geologiske Undersøgelse II. Række 50, 266 pp.

Gravesen, P., Binderup, M., Nilsson, B. \& Pedersen, S.A.S. 2011: Geological characterisation of potential disposal areas for radioactive waste from Risø, Denmark. Geological Survey of Denmark and Greenland Bulletin 23, 21-24.

Gravesen, P., Nilsson, B., Binderup, M., Larsen, T.B. \& Pedersen, S.A.S. 2013: Geology, seismic activity and groundwater conditions at six potential disposal sites for radioactive waste from Risø, Denmark. Geological Survey of Danmark and Greenland Bulletin 28, 13-16.

Gravesen, P., Nilsson, B., Rasmussen, P. \& Pedersen, S.A.S. 2014: Borehole logs from the Precambrian basement on Bornholm, eastern Denmark: geology and groundwater flow. Geological Survey of Danmark and Greenland Bulletin 31, 15-18.

Hansen, M. \& Poulsen, V. (eds) 1977: Geologi på Bornholm, 96 pp. Varv ekskursionsfører 1, København: Tidsskriftet Varv.

Micheelsen, H.I. 1961: Bornholms grundfjæld. Meddelelser fra Dansk Geologisk Forening 14, 308-349.

Miljøcenter Roskilde 2009: Sårbarhedsvurdering af grundvandsressourcen på Nordbornholm, 103 pp. Roskilde: Miljøcenter Roskilde, Miljøministeriet.

Parkhurst, D.L. \& Appelo, C.A.J. 2013: Description of input and examples for PHREEQC version 3 - a computer program for speciation, batch-reaction, one-dimensional transport, and inverse geochemical calculations. U.S. Geological Survey Techniques and Methods, book 6, chapter A43, 497 pp., available only at http://pubs.usgs.gov/tm/06/a43.

Platou, S.W. 1968: On the petrophysical properties of granitic rocks. Geologiska Föreningens i Stockholm Förhandlinger 90, 427-433.

Platou, S.W. 1970: The Svaneke granite complex and the gneisses on east Bornholm. Bulletin of the Geological Society of Denmark 20, 93-133.

Rasmussen, P., Klitten, K., Nielsen, S. \& Jensen, P. 2007: Bornholms Regionskommune. Logging og vandkemi i vandforsyningsboringer, 2006. Danmarks og Grønlands Geologiske Undersøgelse Rapport 2007/36, 175 pp.

von Bubnoff, S. 1942: Beiträge zur Tektonik des skandinavischen Südrandes. 2. Die älteren Granite Bornholms im Rahmen der svekofennidischen Tektogenese. Neues Jahrbuch für Mineralogie, Geologie und Paläontologie, Beilagen-Band 87, 277-396.

Waight, T., Frei, D. \& Storey, M. 2012: Geochronological constraints on granitic magmatism, deformation, cooling and uplift on Bornholm, Denmark. Bulletin of the Geological Society of Denmark 60, 23-46.

Authors' address

Geological Survey of Denmark and Greenland, Øster Voldgade 10, DK-1350 Copenhagen K, Denmark; E-mail:pg@geus.dk 